Article

\title{
Geometric Analysis on Stone Façades with Terrestrial Laser Scanner Technology
}

\author{
Juan Corso $^{1}$, Josep Roca ${ }^{2}$ and Felipe Buill ${ }^{3, *}$ \\ 1 Laboratorio de Modelización Virtual de la Ciudad (LMVC), Universitat Politècnica de Catalunya, \\ 08034 Barcelona, Spain; juan.corso@upc.edu \\ 2 Centre of Land Policy and Valuations, Universitat Politècnica de Catalunya, 08034 Barcelona, Spain; \\ josep.roca@upc.edu \\ 3 Division of Geotechnical Engineering and Geosciences, Universitat Politècnica de Catalunya, \\ 08034 Barcelona, Spain \\ * Correspondence: felipe.buill@upc.edu; Tel.: +34-934011933
}

Received: 11 July 2017; Accepted: 30 September 2017; Published: 10 October 2017

\begin{abstract}
This article presents a methodology to process information from a Terrestrial Laser Scanner (TLS) from three dimensions (3D) to two dimensions (2D), and to two dimensions with a color value (2.5D), as a tool to document and analyze heritage buildings. Principally focused on the loss of material in stone, this study aims at creating an evaluation method for loss control, taking into account the state of conservation of a building in terms of restoration, from studying the pathologies, to their identification and delimitation. A case study on the Cathedral of the Seu Vella de Lleida was completed, examining the details of the stone surfaces. This cathedral was affected by military use, periods of abandonment, and periodic restorations.
\end{abstract}

Keywords: Terrestrial Laser Scanning; orthoimage; heritage; remote sensing; preservation; archaeology

\section{Introduction}

Historic buildings in urban areas often show accelerated deterioration. In historic stone buildings, many different types of damage can occur including: loss of stone material, discoloration, deposits, detachment, fissures, deformation, and damage from previous intervention [1]. Detection of material degradation in historic buildings with traditional methods, such as manual mapping or simple eye examination by an expert [2], are considered time-consuming [3] and laborious procedures, so TLS (Terrestrial Laser Scanner) technology and image processing methodologies are being developed, allowing for the detection of pathologies [4,5], their evolution [6], identification of deformations [7], changes in material [8], and stone façade documentation [9-11].

Understanding this need, this article proposes a methodology for the geometric analysis of stone façades, based on TLS surveys, focusing on the information generated to preserve the architectural heritage [12,13] and its diffusion, as a means to study and analyze [14,15] historical contexts [16,17]. The methodology developed in this article proposes the conversion of three-dimensional (3D) data to two dimensions (2D) $[18,19]$, and two dimensions plus a color value (2.5D) as depth databases (Figure 1).

With precise control of data transformations, the conversion of 2.5D to 3D can be achieved, which is a necessity for the patrimonial documentation [20-24], to the point of generating programs for the work of 3D images [25-28]. This analysis is possible thanks to the use of a geographic information system (GIS) on complex buildings [29,30]. With an emphasis on 3D GIS applied to restoration [31-34].

The goal of applying this process is to perform an analysis that emphasizes the geometric detail of the patrimonial façades, composed mainly of stone. This information would be useful for the diagnosis of stone alterations. As a complementary process, the metric images were used to generate planes in 
vectorial format using a semi-automatic process [35-38], given the quality of definition and thickness of the lines generated.

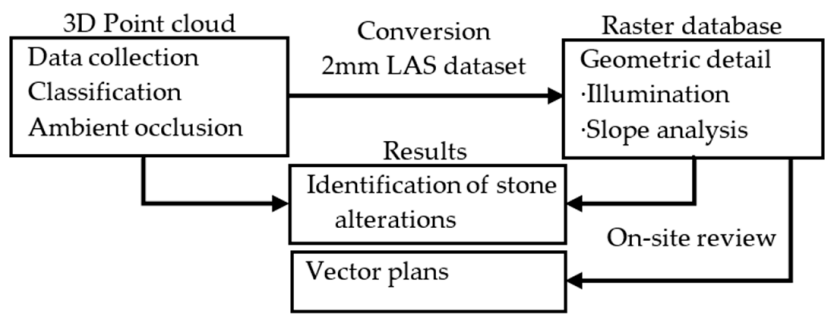

Figure 1. Methodology and structure of the article.

The case study is on the Cathedral of the Seu Vella de Lleida, which is located on the hill known as Turó de Lleida that dominates the city in the Segrià region. The cathedral is designed in a transitional style between Romanesque and Gothic. The Seu Vella de Lleida has Romanesque forms and the monumentality of the Gothic era; it has Gothic cross-vaults. This patrimonial building has suffered damage from several military contests as well as from periods of abandonment [39]. The military uses damaged the building, the most serious of which was caused by civil war bombings-primarily in the terraces and decks—ruining decorative elements like the pinnacles, gables, gargoyles, and the sills of the roof terrace.

During the second half of the 19th century, with the Catalan movement of the Renaissance, the Cathedral was revalued, and around 12 June 1918 it was declared a national monument [40]. In 1948, the army ceded it and restoration began in 1949. During this restoration, the architects Francisco Pons Sorolla and Alexander Ferran made modifications and even replaced some elements. These elements include the traceries and mullions of the Gothic windows, which were reconstructed copying the originals with molds and cement.

There are two types of stone in the study area: the Lleida stone and the Vinaixa stone. They both have intergranular porosity, which is more visible in the Vinaixa stone. A major part of the walls and the base of the cloister of the church are composed of Lleida stone; it is a sandstone rich in carbonates and the texture allows classification like a calcarenite. The Vinaixa stone is found in all the elements that are more or less worked, including arches, capitals, frontons, and traceries. Almost the entirety of the upper part of the cloister is also built with Vinaixa stone [39].

The case study involved surveying the stone with the laser scanner technology, and focused mainly on the gallery of the cloister, which is the green zone shown in Figure 2, which was also a viewpoint of the city of Lleida in the 13th and 14th centuries [39]. This methodology was also applied to other areas of the cathedral with similar stone type characteristics, including to an area of medieval wall, the perimeter of the building, and the door of the Apostles.

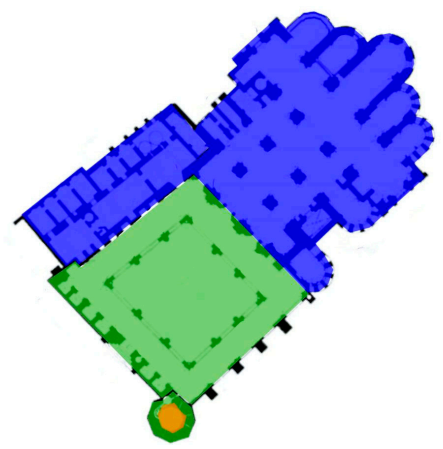

Figure 2. Construction phases: the blue represents the 13th century; the green represents the 14th century; and orange is the 15th century [39]. 


\section{Survey with Terrestrial Laser Scanner Technology}

For data collection, a phase difference scanner was used, the Focus ${ }^{3 \mathrm{D}} 120\left(\mathrm{FARO}^{\circledR}\right.$, Stuttgart, Germany), which allows a wide $360^{\circ} \mathrm{H} \cdot 305^{\circ} \mathrm{V}$ capture range, with an accuracy of $0.6 \mathrm{~mm}$ to $10 \mathrm{~m}$, and $0.95 \mathrm{~mm}$ to $25 \mathrm{~m}$. With a systematic error of $\leq \pm 2 \mathrm{~mm}$ at $25 \mathrm{~m}$, it also captures the information of reflected intensity of the laser and photographic color, with RGB color information assigned to the points, through an integrated camera of 70 megapixels.

Positions were chosen on each arch of the scanned corridor, in the courtyard of the Seu Vella. The scanning resolution was $1 / 8$, with $4 \times$ quality in relation to the scene program, which was used to operate the scanner. The position was obtained by an average of 38 million measures. In total, seven positions were chosen for the gallery of the cloister. In the other zones of the cathedral, 17 positions were selected.

\section{Information Stored in the 3D Point Cloud}

With the aim of documenting the surface geometry of the scanned elements, a set of high resolutions measures, of at least one point every $2 \mathrm{~mm}$ [3], was required. The information generated was stored as scalar values as a 3D cloud of points, which would later be converted into 2D raster databases. The resolution used and the ability store data in 3D clouds of points and 2D raster maintains the following analyses in the database: curvature analysis of the surfaces, direction of surfaces, classification of surfaces, and controlled lighting on surfaces, as shown in Figure 3.

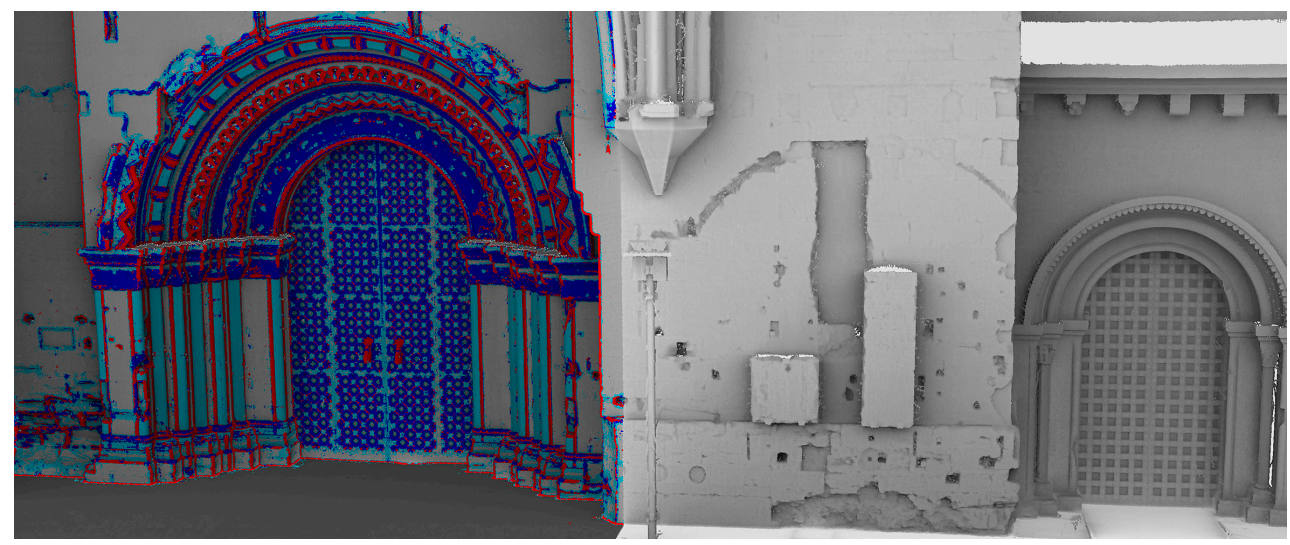

Figure 3. 3D point cloud. CANUPO classification and illumination by ambient occlusion [11]. Classification: floor is shown in gray, the walls are blank, the ornamental elements are shown in blue, and the linear elements in red.

\subsection{Classification of the 3D Point Cloud}

The technique used for this classification, CANUPO, is a set of applications designed for the classification of natural environments, including rivers, coastal environments, cliffs, etc. This process is defined as:

... a multi-scale measure of the point cloud dimensionality around each point.

The dimensionality characterizes the local 3D organization of the point cloud within spheres centered on the measured points and varies from being 1D (points set along a line), $2 \mathrm{D}$ (points forming a plane) to the full 3D volume. By varying the diameter of the sphere, we can thus monitor how the local cloud geometry behaves across scales [41].

Classification was completed by dividing walls as planes, and the other surfaces, on scales between $5 \mathrm{~cm}$ and $30 \mathrm{~cm}$, as shown on the right side of Figure 3. Linear and ornamental elements are also classified, on scales between $2 \mathrm{~cm}$ and $10 \mathrm{~cm}$, with red denoting linear elements, dark blue defining ornamental elements, and light blue for curved surfaces. 
This classification not only included constructive elements; CANUPO classifies everything in the architectural heritage, which requires the interpretation of a specialist. An example of these possible interpretations is the description of isolated elements that make up the building, like the tombs of nobles. In the classification, we identified changes in surfaces, such as edges, planes, or volumes. The identifier of the point cloud was introduced as data, and a number for each point was assigned. The return field was used as a second classification, which can hide elements that are not taken into account in subsequent steps of conversion to raster images-such as the ceiling, furniture, or the floor itself-so that clear information on walls of the façade remained.

\subsection{Details of Surfaces with Lighting Processes}

For geometric analysis, apply lightning processes to the point cloud is useful. These techniques allow the identification of areas that are poorly visible, including concavities of the surface in rough areas, alterations of the material, or simply holes in the surface.

For this kind of analyses, we used the Screen Space Ambient Occlusion [42], with the Plugin qSSAO in Cloudcompare. This is a shading 3D method which adds realism to the models, through the attenuation of the light due to reflection and occlusions that are produced by the geometry of the model (Figure 4).

The calculation of the surface occlusions starts from a virtual lighting process. This lighting obscures the areas in which light rays bounce between nearby surfaces; the more concave the surface the more impacts it receives, and the greater value it acquires. If the surface is more exposed to the exterior, the fewer impacts it receives. If the surface is perpendicular to the sky, it will not darken, keeping its base color.

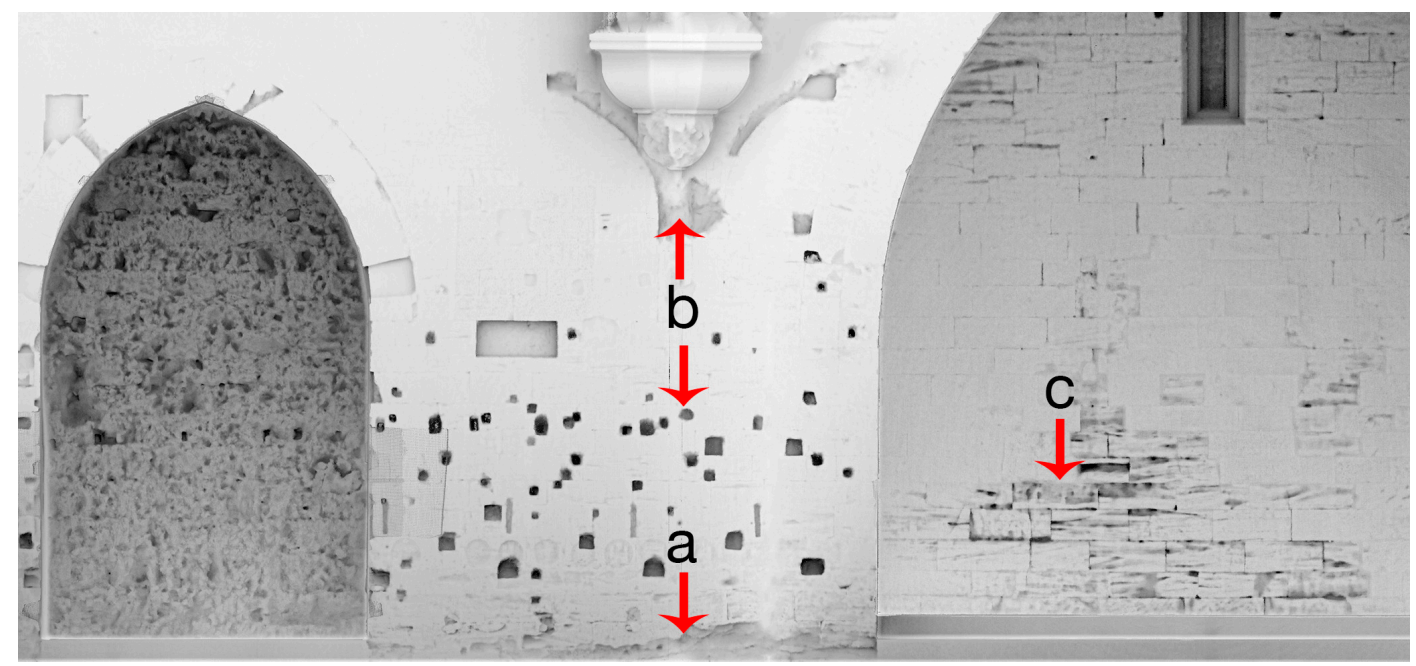

Figure 4. 2D raster from an environmental occlusion generated in 3D: (a) loss of material; (b) holes and alterations of the stone; and (c) disintegration of stone.

\section{3D to $2 \mathrm{D}$ and 2.5D Conversions}

In order to efficiently communicate the desired information in the results of the analyses, a conversion of the $3 \mathrm{D}$ database to $2 \mathrm{D}$ must be completed without losing any information in the process, while maintaining the possibility of reverting to a 3D model. For the front façade, the façades perpendicular to this had to be developed in 2D (2.5D).

To do this, the proposed method starts in LiDAR format, and the LAS dataset, which allows the organization of the topology of the points, including variables such as color, elevation, class, and return as a second classification and intensity. The LAS dataset is able to include extensive point clouds, and is structured to allow adequate information management, with different levels of detail, according 
to the distance. An example is an LAS dataset with depth information and a roughness raster with a roughness range of red to black.

These files allow the generation of the LAS dataset to raster with a GIS. In this case study, the conversion was completed with the ArcGIS program (version 10.1, Environmental Systems Research Institute, Redlands, CA, United States). With a 2-mm subsampled point cloud, this LAS was converted to raster images with a cell value of $2 \mathrm{~mm}$.

The zones that do not have a measurement every $2 \mathrm{~mm}$ were interpolated, applying the maximum distance range between cells function, in this case with a maximum of 3 pixels, $6 \mathrm{~mm}$ in terms of measurements, so that interpolating surfaces that are not related were avoided.

\section{Differences and Relationships between $3 D$ and 2D (2.5D) Information}

Transforming 3D information to $2 \mathrm{D}$ as a metric map facilitates on-site work, allows a direct verification of the information developed, and provides true dimensions of all the elements. As a graphic representation, these are all advantages because an architectural plane provides a better reading and references all aspects of the surface of the building, thus giving a better understanding of complex heritage buildings. However, 3D information is also fundamental, since it allows a volumetric understanding of the building; 3D and 2D (2.5) are complementary [43,44]. Working only in 3D limits the inspection of the building and the work of different disciplines involved. Working only in 2D requires over-segmentation of the façade, avoids self-occlusion of the surface, each one with different deformations, and would thus prevent reading the façade as a whole.

The 3D representation of a point cloud depends on the position of the camera from which the 3D point cloud is rendered and the point size (Figure 5a), while in 2D it depends on the chosen metric image resolution (Figure 5b). Both 3D and 2D information allows operations to be performed. For example, the information of the point cloud allows the performance of operations between the data, generating new databases without altering the base information. As scalar values, the 3D point cloud can store as many scalar value fields as needed.

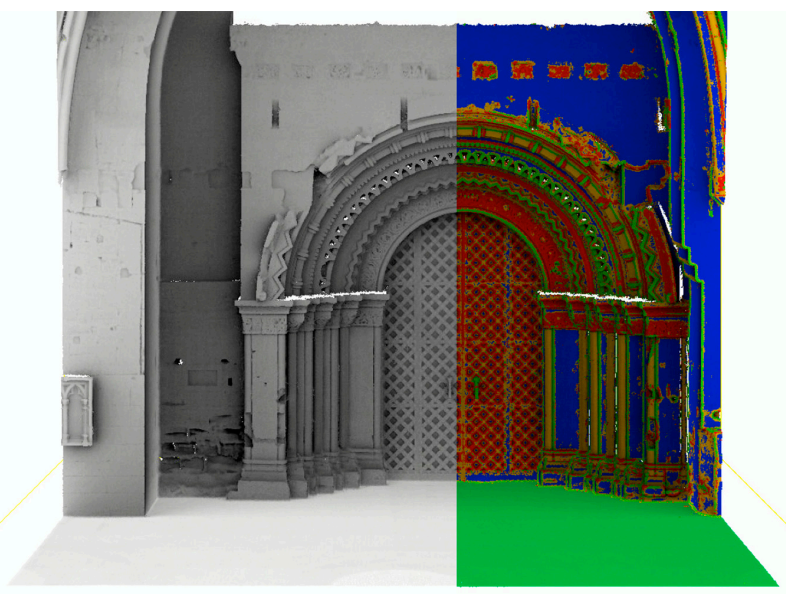

(a)

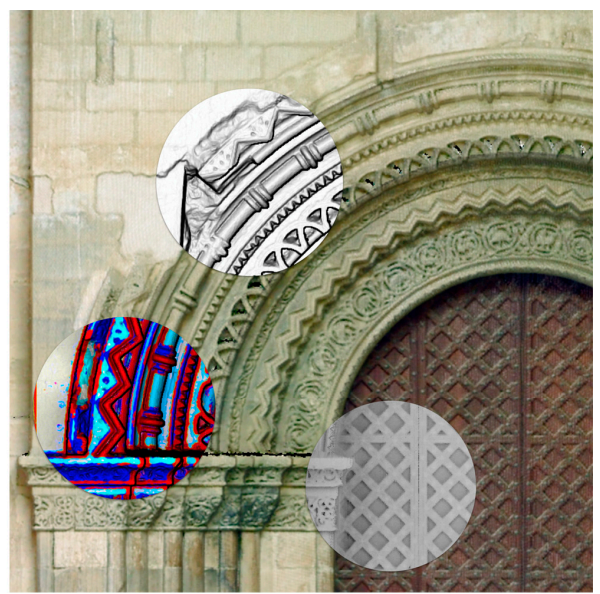

(b)

Figure 5. Layers of information in: (a) 3D point cloud information with factor scales: ambient occlusion and classification; (b) superimposed raster images.

In 2D, the images with scale generate specific documentation; each image is a layer of information with a determined purpose, and these images can be superimposed or interpolated to analyze specific aspects.

Since raster information is controlled, it is possible to return that information to a 3D model. In this process, it is essential to maintain the metadata of the data conversions to be able to reverse the information, or to track the alterations of the obtained results. In addition, maintaining the metadata 
supports other disciplines that work in specific formats by maintaining the metric precision and the position of the data.

\section{Raster Information}

TLS technology makes it possible to generate images with a high degree of precision, providing geometric information on the façades. This information allows the generation of derivative products, such as a Digital Elevation Model (DEM). The DEM complements the 2D data with the information in 2.5D [45], merging this information with the raster. This allows performance analysis, emphasizing the geometric variables of the building, using topography or aerial LiDAR, while retaining the possibility of returning to a 3D model.

\subsection{Geometric Details with Illumination Process}

A DEM not only contains explicit information about elevation in a surface, but also regarding distance and neighborhood relationships. Operations can then be performed on the superficies, which is common in topographic analyses, such as hillshade or slope analysis, Figure 6.
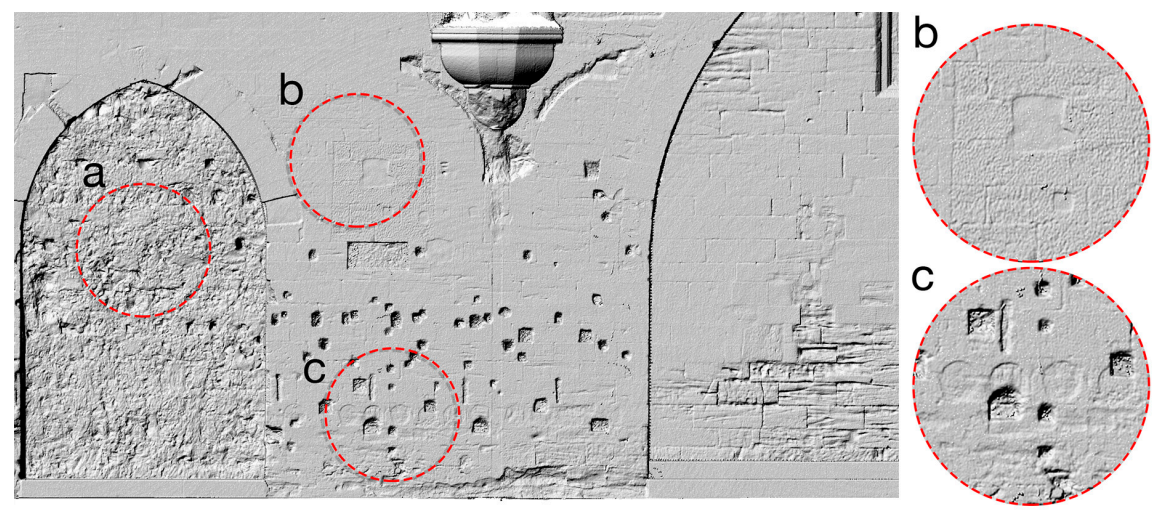

Figure 6. Raster hillshade $315^{\circ}$ azimuth $45^{\circ}$ : (a) surface roughness not visible from photographs, (b) surface roughness not visible to the naked eye, and (c) carved symbols, barely visible on site.

This process can be avoided by applying a mean filter on the points, eliminating the points outside the average, so in this case, the ones corresponding to the points of the lower plane are removed because they are random data due to lack of data in the upper plane. This mean filter was applied to all the images, ensuring information relevant to the objectives of the case study was not lost.

\subsection{Representation of Façade Details from a Slope Analysis}

A slope analysis in GIS identifies the boundaries between surfaces; making it possible to obtain details at different scales and with different magnitudes. Slope analysis is understood as the maximum height change ratio between one cell and the eight neighboring cells. Slope analysis can also be defined as the angle between the vector normal to the surface at that point and the vertical.

As metric planes, the images allow a clear interpretation of the building. The images identify, for example, the patterns in the stones, which is useful for different disciplines, such as for the identification of stratigraphic units of a façade in archaeology [46,47]. Details with little relief have a lower line value than jumps between surfaces or larger planes.

In this case study, the slope analysis was performed with the ArcGIS program, with the technique developed by Burrough et al. [48]. A slope analysis, in which an accurate representation of the shapes and geometries of the elements are distinguished, is seen in Figure 7. 


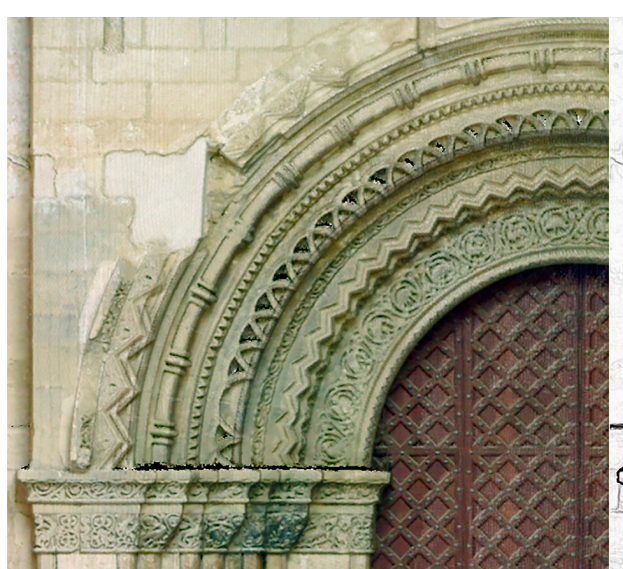

(a)

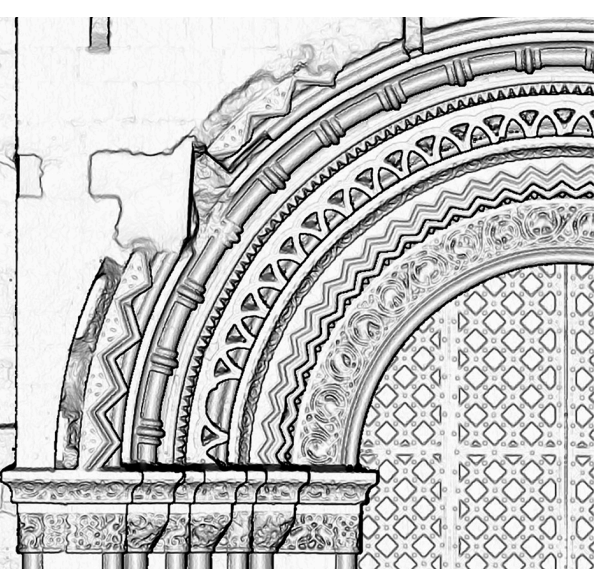

(b)

Figure 7. Identification of previous interventions with different materials: (a) identification of alterations in geometric patterns and (b) slope raster obtained through DEM spatial analysis.

\section{Identification of Alterations in the Stone by Combining Raster Images}

Stone decay can be either additive or subtractive [1]. The DEM identifies the depth differences between planes of a surface and from this, can identify the boundaries between these surfaces (Figure 8a). Even in this image, whether the material is loose or will gain material as part of the decay mechanism cannot be identified. For this reason, the metric image of Figure $8 \mathrm{~b}$ is generated. The ambient occlusion is projected onto the 3D model and generates an image that identifies the concavities of the surfaces, and with it, the loss of the material. In this zone, the sandstone and disintegration of the stone is identified. This occurs because of the presence of clays in the Lleida stone; these clays degrade with a certain speed, and the water in the stone causes the clay to expand, creating internal tensions that lead to the disintegration of the material near the surface of the element.

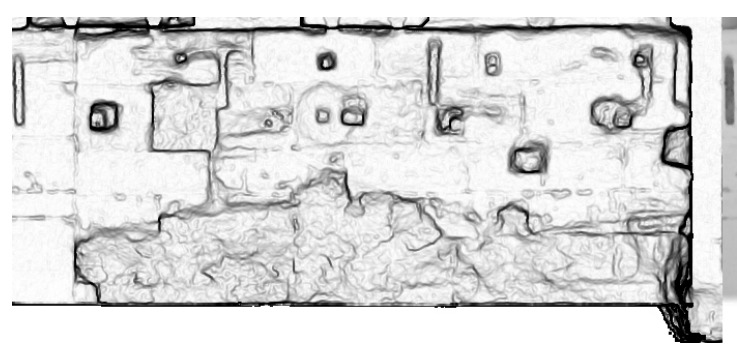

(a)

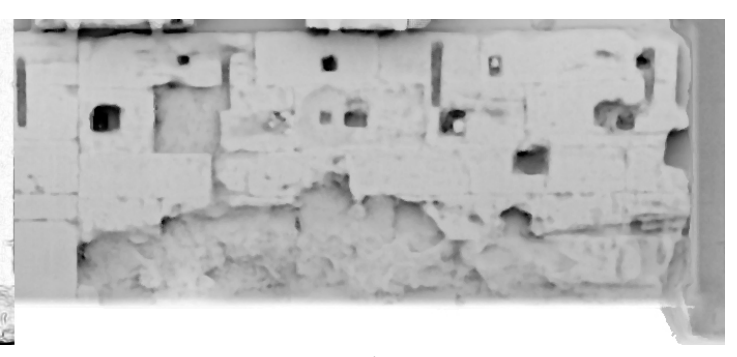

(b)

Figure 8. Deterioration of the stone: (a) the boundaries between surfaces, the slope, is identified; and (b) the sandstone is identified as well as the disintegration of the stone (ambient occlusion).

Identification of different materials, using RGB images combined with images of lighting techniques and observation on site, shows complete blocks of restored stone, different from those around them. This information helps to delimit the area that has been restored and identify blocks that suffer from disintegration (Figure 9). The stone substitutions were made with Vinaixa stone, as it does not suffer from the same degradation as that from Lleida.

The stone degradation is also visible in other areas, like in the lower area on the left side of the Nave del Aepístola (Figure 9). In this area, a different type of material loss is present, seen in the loss of its clay base caused by water [49]. The generated images identify the limits of the alterations and quantify the loss of material. A study of this type would enable management actions of the patrimonial property, would provide more information to help better manage the conservation processes, and verify that the pathology does not worsen. 


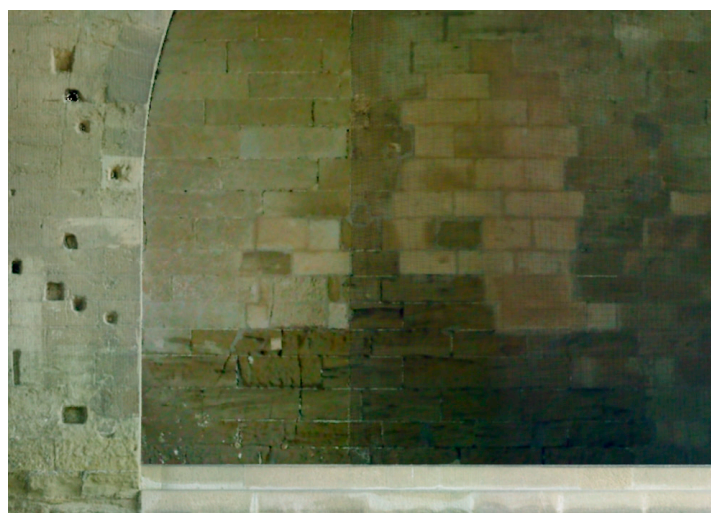

(a)

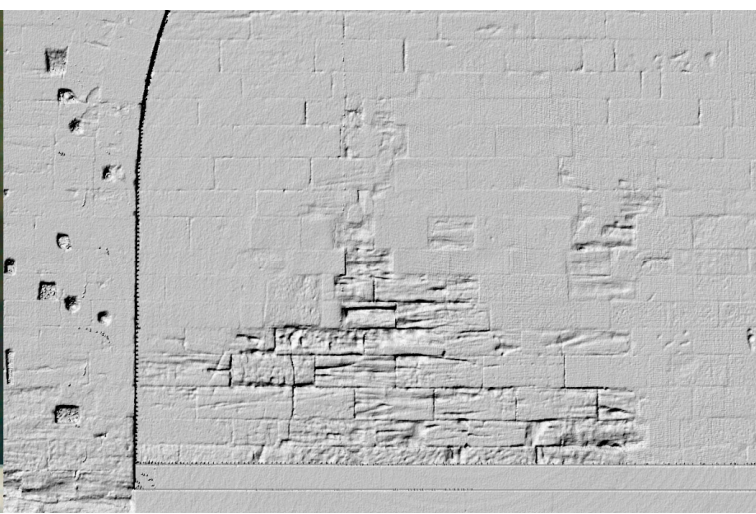

(b)

Figure 9. Identification of previous interventions with different stone: (a) RGB left; and (b) disintegration of stone (hillshade).

Using only one color image with RGB information is not sufficient to perform an analysis for directing restoration efforts on a heritage building. The singular image lacks important information. For example, the roughness of the surface, shown in Figure 10, is shown as a continuous surface in a RGB image, but the ambient occlusion shows the actual stone deterioration.

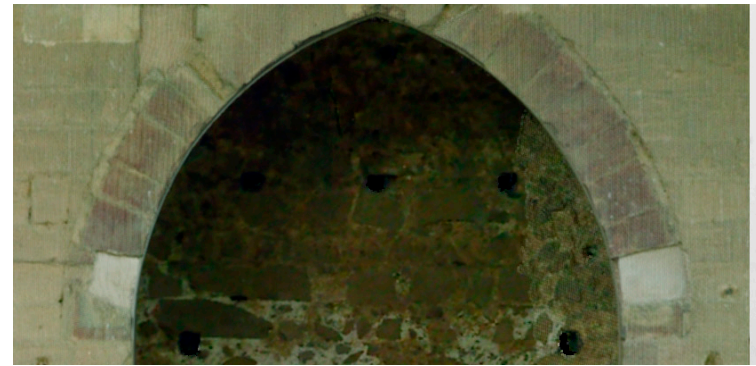

(a)

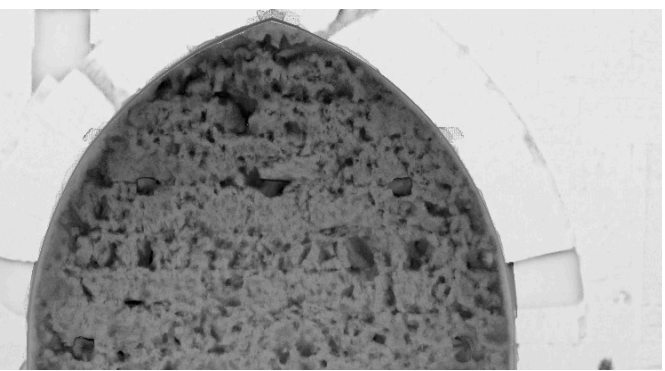

(b)

Figure 10. Efflorescence in the stone: (a) the RBG image showing a smooth surface; and (b) deterioration of the stone by alveolization of the materials shown by ambient occlusion.

This deterioration, the loss of material by alveolization, is a phenomenon characterized by the formation of voids or cavities of different sizes and morphologies, called alveoli. Its appearance depends on the composition of the rock and environmental factors [50].

A partial loss of the volume or an erosion of the stone can occur due to the consolidation of the stone, for example, with the application of replacement mortar. This erosion or loss of material must be documented for its control.

\section{Semiautomatic Process to Convert Vector Planes}

To obtain images that can be edited and are ready for specialists, the $2 \mathrm{D}$ images must be vector planes. Converting this information to a $2 \mathrm{D}$ vector plane is performed through a semiautomatic process, in which a raster image is created and converted to a vector plane.

The first step is performing a curvature analysis in relation to the scale of the desired vector plane, accounting for the detail that would be seen on the determined scale. In this process, it is important to consider the resolution of the data acquisition and the noise generated in the data capture [51].

Next, the raster lines are converted to vector lines, with a program like AutoCAD Raster Design, which allows image analysis and subsequent vectorization (Figure 11). In this process, manual editing is needed for areas requiring interpretation, or areas with occlusions of the data collection, and to 
simplify or clean areas of difficult interpretation. In the same way, manual editing is necessary to separate the layers [52], taking into account the value of the line and the representation of the plane.

The complete process from point cloud conversion to DEM generation, slope analysis, and vectorization required two hours to complete, plus $15 \mathrm{~min}$ of zone correction per occlusion, and $30 \mathrm{~min}$ to reorder layers, depending on the value of the line. Drawing only one of the doors in CAD, manually, took a day of work [3]; the entire façade would be a week due to the complexity of the decorations.

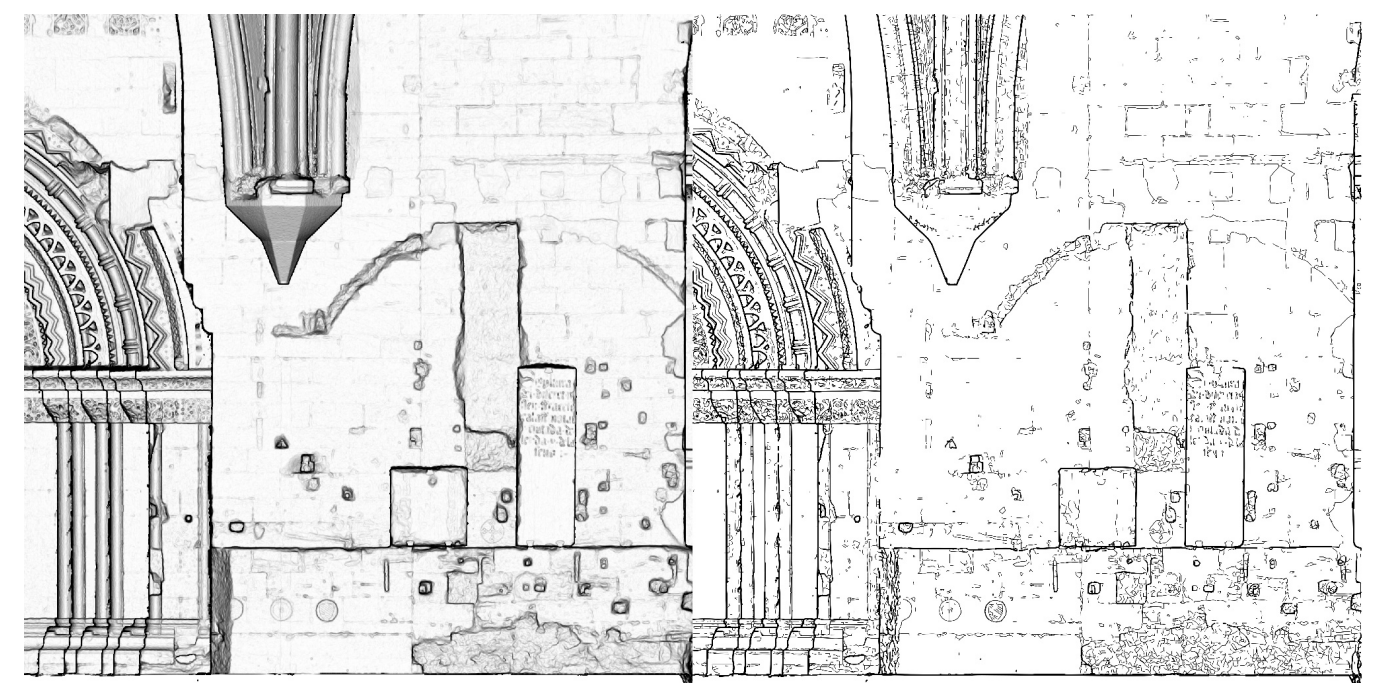

(a)

(b)

Figure 11. Raster to vector conversion: (a) curvature analysis; and (b) vector planimetry from the curvature analysis.

\section{Conclusions}

As shown in the literature, there is a growing use of GIS and image processing with TLS surveys, which relate the 3D models to 2D maps; low-resolution models are created and mapped, documenting the starting information in 3D and expanding the information as images [18-24]. A new methodology is developed in this article-a 3D controlled conversion to $2 \mathrm{D}$ and $2.5 \mathrm{D}$ - that operates without interpolations and reduces the loss of base information, enabling the conversion of new information generated in 2D and 2.5D to a 3D model (point cloud), recording the rasters as a database. This allows for comparison of the differences in the storage of information between raster and point cloud.

According to the methodology, a case study is developed, establishing parameters of graphical representations and highlighting features associated with stone pathologies, such as analysis of the patrimonial building surface, which complement the field work of the restoration.

For the Seu Vella, the raster images showed the delimited areas with deterioration in the stone, and the behavior of the Vinaixa and Lleida stone in the cathedral were identified. We determined that the Lleida stone, the predominant rock in this cathedral, suffers significant erosion, both in loss of material and in alveoli formation in all orientations, produced by the presence of water and by the mineralogy of the stones rich in clays.

This comparison between layers of raster images and their relationship to the 3D model with an on-site review, allows us to detect the change in stone type through surface roughness, stone relief, stone erosion or alteration, the boundaries between surface planes, and the color of the stones.

This study helps work toward achieving preservation of buildings, with a focus on prevention and maintenance work, which contributes to their protection. This raster information allowed us to generate vectorial plans, and the adopted technique leads to an improvement of the heritage register compared to traditional techniques that are currently used to produce stone-by-stone elevations. 
Author Contributions: Juan Corso and Felipe Buill designed the methodology, conceived and designed the experiments; Juan Corso performed the experiments; Juan Corso and Josep Roca analyzed the data; Josep Roca contributed the material of the case study; Juan Corso wrote the paper.

Conflicts of Interest: The authors declare no conflict of interest.

\section{References}

1. Kottke, J. An Investigation of Quantifying and Monitoring Stone Surface Deterioration Using Three Dimensional Laser Scanning. Master's Thesis, University of Pennsylvania, Philadelphia, PA, USA, 2009.

2. Almagro, A. Simple methods of photogrammetry-Easy and fast. Int. Arch. Photogramm. Remote Sens. Spat. Inf. Sci. 2002, 34, 32-38.

3. Barber, D.M.; Dallas, R.W.; Mills, J.P. Laser scanning for architectural conservation. J. Archit. Conserv. 2006, 12, 35-52. [CrossRef]

4. Seif, A.; Santana, M.; KreidI, J. Protecting Baalbek's Integrity, "A Proposal for an Integrated Risk Preparedness Strategy"; UNESCO: Beirut, Lebanon, 2011; ISBN 9789081695305.

5. ICOMOS; ISCS. Illustrated Glossary on Stone Deterioration Patterns. Available online: http://www.icomos. org/publications/monuments_and_sites/15/pdf/Monuments_and_Sites_15_ISCS_Glossary_Stone.pdf (accessed on 1 October 2017).

6. Fregonese, L.; Biolzi, L.; Bocciarelli, M. Surveying and monitoring for vulnerability assessment of an ancient building. Sensors 2013, 13, 9747-9773. [CrossRef] [PubMed]

7. Pescia, A.; Bonalib, E.; Gallib, C. Laser scanning and digital imaging for the investigation of an ancient building: Palazzo d'Accursio study case (Bologna, Italy). J. Cult. Herit. 2012, 13, 215-220. [CrossRef]

8. Pozo, S.; Herreo, J.; Felipe, B.; Hernández, D.; Rodríguez, P.; González, D. Multispectral radiometric analysis of façades to detect pathologies from active and passive remote sensing. Remote Sens. 2016, 8, 80. [CrossRef]

9. Drap, P.; Durand, A.; Nidir, M. Photogrammetry and archaeological knowledge: toward a 3D information system dedicated to medieval archaeology: A case study of Shawbak Castle in Jordan. In Proceedings of the 3D ARCH 2007, Zürich, Switzerland, 12-13 July 2007.

10. Willis, A.; Sui, Y. Estimating gothic facade architecture from imagery. In Proceedings of the IEEE Computer Society Conference on Computer Vision and Pattern Recognition Workshops (CVPRW), San Francisco, CA, USA, 13-18 June 2010.

11. Burgerb, A.; Grimm-Pitzinger, A.; Thaler, E. A combination of modern and classic methods of surveying historical buildings-The Church St. Valentin in the South Tyrol. In Proceedings of the XXI International CIPA Symposium, Athens, Greece, 1-6 October 2007.

12. Van Genechten, B. Theory and Practice on Terrestrial Laser Scanning: Training Material Based on Practical Applications; Universidad Politecnica de Valencia Editorial: Valencia, Spain, 2008; ISBN 9788483633120.

13. Charter, V. International Charter for the Conservation and Restoration of Monuments and Sites. Second International Congress of Architects and Technicians of Historic Monuments. Available online: http:/ / www.icomos.org/charters/venice_e.pdf (accessed on 1 October 2017).

14. Allen, K.M.S.; Zubrow, E.B.W. Interpreting Space: GIS and Archaeology; Taylor \& Francis: London, UK, 1990; ISBN 9780850668247.

15. Conolly, J.; Lake, M. Geographical information systems in archaeology. In Cambridge Manuals in Archaeology; Cambridge University Press: Cambridge, UK, 2006; ISBN 9780521793308.

16. Pieraccini, M.; Guidi, G.; Atzeni, C. 3D digitizing of cultural heritage. J. Cult. Herit. 2001, 2, 63-70. [CrossRef]

17. Berndt, E.; Carlos, J. Cultural heritage in the mature era of computer graphics. IEEE Comput. Graph. Appl. 2000, 20, 36-37. [CrossRef]

18. Salonia, P.; Negri, A. Cultural Heritage emergency: GIS-based tools for assessing and deciding preservation and management. In Proceedings of the Twenty-Third Annual ESRI International User Conference, San Diego, CA, USA, 7-11 July 2003.

19. Bartolomucci, C. Una proposta di cartella clinica per la conservazione programmata. Arkos Sci. Restaur. Archit. 2004, 5, 59-65.

20. Aldenderfer, M.; Maschner, H.D. (Eds.) Anthropology, Space, and Geographic Information Systems; Oxford University Press: Oxford, UK, 1996; ISBN 9780195085754. 
21. Campanaro, D.M.; Landeschi, G.; Dell'Unto, N.; Touati, A.M.L. 3D GIS for cultural heritage restoration: A 'white box' workflow. J. Cult. Herit. 2016, 18, 321-332. [CrossRef]

22. Canciani, M.; Ceniccola, V.; Messi, M.; Saccone, M.; Zampilli, M. A 3D GIS method applied to cataloging and restoring: The case of Aurelian Walls at Rome. ISPRS Int. Arch. Photogramm. Remote Sens. Spat. Inf. Sci. 2013, 1, 143-148. [CrossRef]

23. Dell'Unto, N.; Landeschi, G.; Apel, J.; Poggi, G. 4D recording at the trowel's edge: Using three-dimensional simulation platforms to support field interpretation. J. Archaeol. Sci. Rep. 2017, 12, 632-645. [CrossRef]

24. Landeschi, G. Assessing the damage of an archaeological site: New contributions from the combination of image-based 3D modelling techniques and GIS. J. Archaeol. Sci. Rep. 2016, 10, 431-440. [CrossRef]

25. Pedelì, C. An interdisciplinary conservation module for condition survey on cultural heritages with a 3D information system. ISPRS Int. Arch. Photogramm. Remote Sens. Spat. Inf. Sci. 2013, 2, 483-487. [CrossRef]

26. Janvier-Badosa, S.; Stefani, C.; Brunetaud, X.; Beck, K.; De Luca, L.; Al-Mukhtar, M. Documentation and analysis of 3D mappings for monument diagnosys. In Built Heritage: Monitoring Conservation Management; Springer: Cham, Switzerland, 2014; pp. 347-357. ISBN 9783319085333.

27. Brunetaud, X.; Luca, L.D.; Janvier-Badosa, S.; Beck, K.; Al-Mukhtar, M. Application of digital techniques in monument preservation. Eur. J. Environ. Civ. Eng. 2012, 16, 543-556. [CrossRef]

28. Stefani, C.; Brunetaud, X.; Janvier-Badosa, S.; Beck, K.; De Luca, L.; Al-Mukhtar, M. Developing a toolkit for mapping and displaying stone alteration on a web-based documentation platform. J. Cult. Herit. 2013, 15, 1-9. [CrossRef]

29. Salonia, P.; Messina, T.L.; Marcolongo, A.; Appolonia, L. Photo scanner 3D survey for monitoring historical monuments. The case history of Porta Praetoria in Aosta. Geoinform. FCE CTU 2011, 6, 314-322. [CrossRef]

30. Bartolomucci, C.; Trizio, I.; Bonzagni, D. The reintegration of urban lacunas at castelvecchio calvisio (AQ) after the 2009 earthquake: The use of GIS 3D as a project monitoring tool. In Proceedings of the 4th International Conference on Progress in Cultural Heritage Preservation, Limassol, Cyprus, 29 October-3 November 2012; pp. 586-593.

31. Lock, G. Theorising the practice or practicing the theory: Archaeology and GIS. Archaeol. Polona 2001, 39, 153-164.

32. Lock, G.R. Using Computers in Archaeology: Towards Virtual Pasts; Routledge: New York, NY, USA, 2003; ISBN 9780415167703.

33. Haklay, M.E. Virtual reality and GIS: Applications, trends and directions. In Virtual Reality in Geography; Taylor \& Francis: New York, NY, USA, 2002; pp. 47-57.

34. Dell'Unto, N. The use of 3D models for intra-site investigation in archaeology. In 3D Recording and Modeling in Archaeology and Cultural Heritage; Archaeopress: Oxford, UK, 2014; ISBN 9781407312309.

35. Lymer, K. Image processing and visualisation of rock art laser scans from loups's hill, county durham. Digit. Appl. Archaeol. Cult. Herit. 2015, 2, 155-165. [CrossRef]

36. Pesci, A.; Casula, G.; Boschi, E. Laser scanning the Garisenda and Asinelli towers in Bologna (Italy): Detailed deformation patterns of two ancient leaning buildings. J. Cult. Herit. 2011, 12, 117-127. [CrossRef]

37. Pesci, A.; Teza, G.; Bonali, E.; Casula, G.; Boschi, E. A laser scanning-based method for fast estimation of seismic-induced building deformations. ISPRS J. Photogram. Remote Sens. 2013, 79, 185-198. [CrossRef]

38. Arias, P.; Herraez, J.; Lorenzo, H.; Ordonez, C. Control of structural problems in cultural heritage monuments using close-range photogrammetry and computer methods. Comput. Struct. 2005, 83, 1754-1766. [CrossRef]

39. Gainza, M. El deterioro de la Piedra en el Patrimonio Construido y Aplicación de Nanoformulaciones Para la Conservación de los Mismos. Master's Thesis, Universitat Politècnica de Catalunya, Barcelona, Spain, 2015.

40. Macià, M. La Seu Vella de Lleida: Guia Històrica i Arquitectónica; Generalitat de Catalunya, Departament de Cultura: Barcelona, Spain, 1997; ISBN 8439344120, 9788439344124.

41. Brodu, N.; Lague, D. 3D terrestrial lidar data classification of complex natural scenes using a multi-scale dimensionality criterion: Applications in geomorphology. ISPRS J. Photogramm. Remote Sens. 2012, 68, 121-134. [CrossRef]

42. Aalund, F. A Comparative Study of Screen-Space Ambient Occlusion Methods. Bachelor Thesis, Technical University of Denmark Informatics and Mathematical Modelling, Kgs. Lyngby, Denmark, 2013.

43. Barber, D.; Mills, J.; Andrews, D. 3D Laser Scanning for Cultural Heritage: Advice and Guidance to Users on Laser Scanning in Archaeology and Architecture; Technical Report; English Heritage: Swindon, UK, 2011. 
44. Andrés, M.A.N.; Pozuelo, F.B. Evolution of the architectural and heritage representation. Landsc. Urban Plan. 2009, 91, 105-112. [CrossRef]

45. De Reu, J.; Plets, G.; Verhoeven, G.; De Smedt, P.; Bats, M.; Cherretté, B.; De Maeyer, W.; Deconynck, J.; Herremans, D.; Laloo, P.; et al. Towards a three-dimensional cost-effective registration of the archaeological heritage. J. Archaeol. Sci. 2013, 40, 1108-1121. [CrossRef]

46. Mileto, C.; Vegas, F. El análisis estratigráfico: Una herramienta de conocimiento y conservación de la arquitectura. In España: Arqueología Aplicada al Estudio e Interpretación de Edificios Históricos, Últimas Tendencias Metodológicas; Ministerio de Cultura: Madrid, España, 2011; pp. 145-157.

47. Fiorini, A.; Urcia, A.; Archetti, V. The digital 3D survey as standard documentation of the archaeological stratigraphy. In Proceedings of the 12th International Symposium on Virtual Reality, Archaeology and Cultural Heritage VAST, Prato, Italy, 18-21 October 2011.

48. Burrough, P.; McDonell, R. Principles of Geographical Information Systems; Oxford University Press: New York, NY, USA, 1998.

49. Pancorbo, F. Corrosión, Degradación y Envejecimiento de los Materiales Empleados en la Edificación; Marcombo, S.A.: Barcelona, Spain, 2010; ISBN 8426715761, 9788426715760.

50. Valdeón, L.; Esbert, R.; Marcos, R. La alveolización y otras formas de alteración desarrolladas sobre las areniscas del palacio de Revillagigedo de Gijón (Asturias). Mater. Constr. 1985, 35, 41-48. [CrossRef]

51. Jacobs, G. Understanding spot size for laser scanning. Prof. Surv. Mag. 2006, 26, 48-50.

52. Almagro, A. Levantamiento Arquitectónico, volumen 8 de Monográfica (Universidad de Granada): Biblioteca de Arquitectura, Urbanismo y Restauración; Universidad de Granada: Granada, Spain, 2004; ISBN 8433831909, 9788433831903.

(c) 2017 by the authors. Licensee MDPI, Basel, Switzerland. This article is an open access article distributed under the terms and conditions of the Creative Commons Attribution (CC BY) license (http://creativecommons.org/licenses/by/4.0/). 